\title{
Implementation Of The Nature Of Science And Social Sciences In The World Of Education
}

\author{
Sahbuki Ritonga ${ }^{1)}$, Zulpahri Nainggolan ${ }^{2)}$, Soybatul Aslamiah Ritonga ${ }^{3)}$, Raden Sri Ayu Ramadhana ${ }^{4)}$ \\ Muhammad Fauzi Romadhon Marpaung ${ }^{5}$, Wahyu Azhar Ritonga ${ }^{6} *$ \\ ${ }^{1,3)}$ Pendidikan Islam Anak Usia Dini, Sekolah Tinggi Ilmu Tarbiyah Al- Bukhary Labuhanbatu \\ ${ }^{2)}$ Pendidikan Bahasa Indonesia Universitas Islam Labuhanbatu \\ 4) Pendidikan Matematika, Fakultas Keguruan dan Ilmu Pendidikan Universitas Al Washliyah Labuhanbatu \\ ${ }^{5,6)}$ Teknik Informatika, Fakultas Teknik, Universitas Al Washliyah Labuhanbatu
}

*Coresponding Author

Email : wahyuazharrit@gmail.com

\begin{abstract}
Implimentation of the nature of science and social science in the world of education aims to form a mindset and mindset of feeling towards students who are more consistent in learning so that education is realized that gives birth to future generations with a scientific mindset, with concepts, principles, theories and emotional and social intelligence in each individual student. The method of theoretical studies and observations in schools that science and social sciences cannot be separated from the learning process in the world of education, from the results of data testing that we have carried out that social phenomena are always related to their environment. Implementation of the nature of science and social science in the world of education that there are vibrations and energy waves to carry out an activity in learning which essentially already exists in each individual. Data processing results using spss for windows obtained $F_{\text {hitung }}=13.618$ with sig. 0.000 and $F_{\text {hitung }}=8.385$ with sig. 0.001 from for $F_{\text {table }}=3.19$ the results obtained in relation to the implementation is very significant.
\end{abstract}

Keywords: Implementation, Nature, Science and Social, The world of education

\section{INTRODUCTION}

The world of education that is inseparable in our daily lives which is essentially to form a social soul and good character in each individual is very difficult to understand. Science is the whole conscious effort to investigate, discover, and improve human understanding of various aspects of reality in the human realm. These aspects are limited so that certain formulations are produced. Science provides certainty by limiting the scope of its views, and the certainty of the sciences is derived from its limitations. Science is not just knowledge but summarizes a set of knowledge based on agreed theories and can be systematically tested with a set of methods recognized in a particular field of science. (Dafrita, 2015)

It is stated in Law No. 20 of 2003 on the system of "national education serves to develop capabilities and form the character and civilization of a dignified nation in order to educate the life of the nation", which aims to develop the potential of learners to become human beings who believe and fear God Almighty, be noble, healthy, knowledgeable, capable, creative, independent, and become democratic and responsible citizens (UU, 2013) In accordance with the above educational objective law, it is very close to the implementation of the nature of science and social that continues to be developed so that the realization of people who have emotional good relationships with others and positive energy good relationships with 
their creators. In fact, the science already exists in every individual only the process that must be done to grow and develop the vibration of the soul (science) and body (social) through the world of education. In line with the course of change and the development of the age of science began to separate from its parent, namely philosophy. (Widyawati, 2013) There are two types of thought processes, namely algorithmic and heuristic thought processes. Algorithmic is the process of linear, convergent, logical, straight thinking towards a particular target. Heuristic is a divergent, not linear, not straight, illogical, creative thought process towards several targets at once. (Astawa, 2017)

Character education, it is absolutely necessary not only in school but also at home, in social environments (Omeri, 2015) with the implementation of the nature of science and social sciences that are processed in the world of education. Since the development of science and technology the education process has become more advanced. A lot has changed over time due to technology. (Mulyadi, dkk. 2021) The starting point of this integrative development model is where the Qur'an and science can be the source of the formation of theoretical elements to explain reality, which strengthens the study of social sciences as the development of IPS teaching materials applied in madrassas. (Sanusi. 2017) with many studies conducted based on events that occurred, especially in the world of Education for the sake of shared ideals in accordance with the mandate of the 1945 Constitution Education is an effort to realize a generation that is superior and able to compete in the global world. Because education is actually a process of paradigm shifting a person's good thinking. Education is also able to change the mindset of someone so that they can explore themselves. (Utomo, 2019).

\section{RESEARCH METHODS}

The methods used in this research use theoretical study methods or approaches (library research) and observation with various theoretical study materials to help and observation is used as data collection where the research or collaborators record information as directly witnessed during the research, from research sources of journals, news and books that are studies in research that will be conducted, especially for learners in the world of education.

\section{RESULTS AND DISCUSSION}

\section{Implementation Definition}

A policy is an action that leads to a goal proposed by a person, group or government in a particular environment in connection with certain obstacles while looking for opportunities to achieve the goal or realize the desired goal. "Implementation is down to the activity, action, action, or mechanism of a system. Implementation is not just an activity, but a planned activity and to achieve the objectives of the activity." (Usman, 2002:70).

\section{Implementation Objectives}

As previously written, this implementation is an activity or activity that is carried out systematically and bound by mechanisms to be able to achieve certain goals. Referring to the definition of implementation outlined above, below are some of the implementation objectives including the following:

1. The main purpose of implementation is to implement a plan that has been or has been carefully prepared, be it by individuals or groups.

2. To be able to test and also document a procedure in the implementation of the plan or policy. 
3. To be able to realize the goals to be achieved in the planning or also policies that have been or have been designed.

4. To be able to know the ability of the community in implementing a policy or also a plan in accordance with the expected.

5. To be able to find out the success rate of a policy or plan that has been / has been designed for improvement or improvement of quality

Based on theoretical studies from journal sources, the internet, books and other media it is found that in the world of Education the Implementation of the Nature of Science and Social Sciences is very synergistic for a very perfect change, both in action, as well as new activities in the development of mindsets and taste patterns continue to be done to obtain perfection in the scientific and social processes in life.

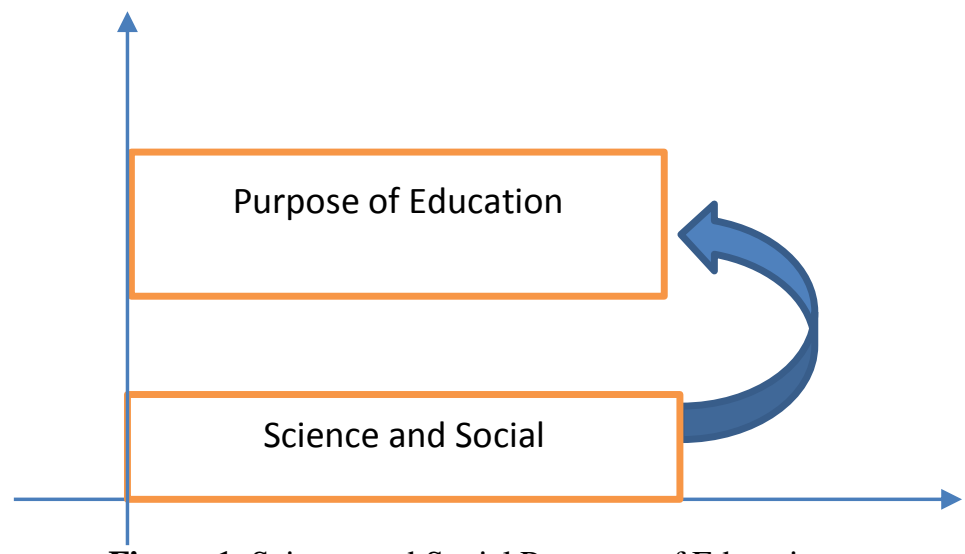

Figure 1. Science and Social Purposes of Education

Science and social synergy to achieve the goal of Education in this case science to improve behavior and attitudes to solve the problems faced are not only aimed at mastery of the content of science itself but directed at the development of skills. In solving social problems that occur in everyday life starting from the world of education with regard to the scientific process.

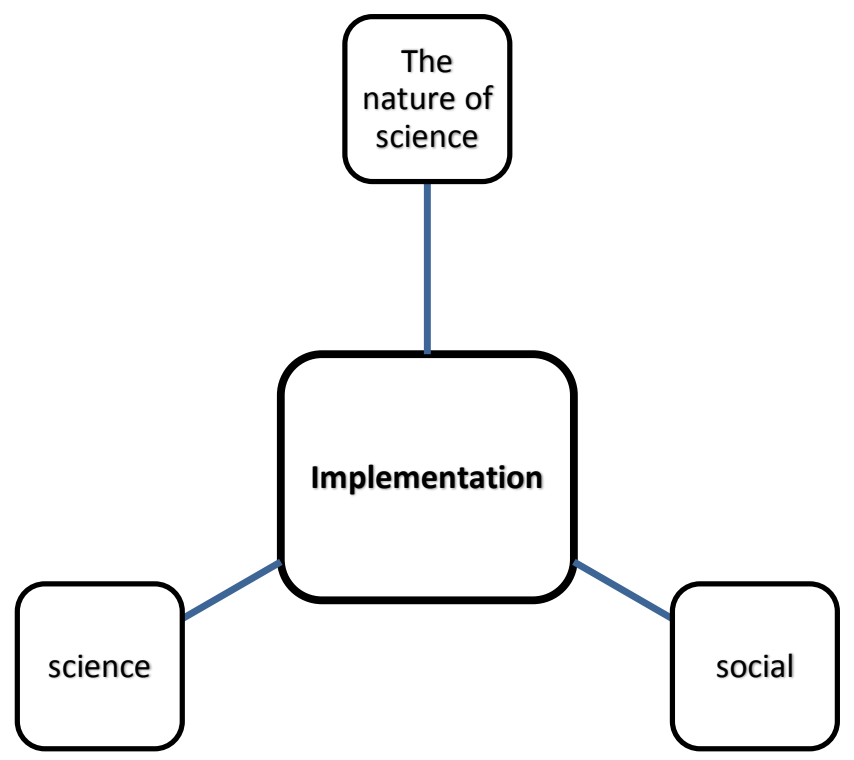

Figure 2. Implementation of the Nature of Science and Social Sciences 
The implementation of the nature of science and social science in the world of education boils down to activities carried out in the world of education to humanize humans by producing a new nature that is basically the nature of the individual self as a basis continues to be developed by collaborating science and social sciences as the purpose of education in Indonesia. The relation of science and social cannot be separated as an implementation in the world of Education. Its main purpose is to establish good ethics and etiquette. with the approach of science as the formation and development of scientific attitudes that will basically be applied in the social environment that is interacting with fellow humans by continuing to increase the intellectual potential of students so that implementation is realized. (hablum minallah and hablum minannas "good relationship with the creator of ourselves and also his fellow creations, especially humans).

Table 1. Data results using SPSS for windows

\begin{tabular}{|c|c|c|c|c|c|c|}
\hline \multicolumn{7}{|c|}{ ANOVA $^{a}$} \\
\hline & Model & Sum of Squares & df & Mean Square & $\mathbf{F}$ & Sig. \\
\hline \multirow{3}{*}{1} & Regression & 96.958 & 1 & 96.958 & 13.618 & $.000^{\mathrm{a}}$ \\
\hline & Residual & 341.762 & 48 & 7.120 & & \\
\hline & Total & 438.720 & 49 & & & \\
\hline \multirow{3}{*}{2} & Regression & 115.374 & 2 & 57.687 & 8.385 & $.001^{\mathrm{c}}$ \\
\hline & Residual & 323.346 & 47 & 6.880 & & \\
\hline & Total & 438.720 & 49 & & & \\
\hline
\end{tabular}

a. Dependent Variable: Hakikat Ilmu Sains dan Sosial

b. Predictors: (Constant), Dunia Pendidikan

For $\mathrm{F}_{\text {table }} \mathrm{N}=50$ is 3.19

c. Predictors: (Constant), Dunia Pendidikan, Implementasi

From data processing using SPSS for windows, it can be seen for $\mathrm{F}=13.618$ with sig 0.001 and $\mathrm{F}=8,385$ with sig. 0.001 shows that the implementation in the world of education is significant if it continues to be developed and implemented it will be better in shaping the ethics and etiquette of every person of education.

To make it easier for us to remember the implementation of the nature of science and social science in the world of Education, we can remember the formula.

In the scientific formula we can see that:

$$
\begin{aligned}
\boldsymbol{W}=\boldsymbol{F} . \boldsymbol{s} \\
\text { Where: } \\
\text { W }=\text { Effort } \\
\mathrm{F}=\text { Style } \\
\mathrm{s}=\text { Displacement }
\end{aligned}
$$

Effort (W) in this case to include science and social science in the mind and heart style (F) pull or re reses that are given to accept positive or negative things by using the mind and heart that always synergize for the purpose in the implementation and change or transfer (s) of the nature of science to our daily lives. So there needs to be a more diligent effort in order to implement the nature of science and social science in the world of education. In other words, unyielding to create an Education that produces ethical and good-mannered people, it does not take much style to make a change or move to humanize humans. 


\section{CONCLUSION}

The nature of science and social science in the world of education as an implementation that continues to be done in order to achieve the goal of education Implementation boils down to activities, action actions or the existence of a system mechanism, implementation is not just an activity but a planned activity and to achieve the perfect goal, so the implementation of the nature of this science must be developed to create the people of the world of education that is perfect, so that humanizing people are achieved..

\section{REFERENCES}

Dafrita, Ivan Eldes. (2015). Science and the nature of science in religious values. IAIN Pontianak Journal, 9(2): 159- 179

I Nyoman Temon Astawa (2017). Theories in the World of Modern Education. Quality Assurance Journal, 67-72

Mulyani,F and Nur.H (2021). Analysis of the Development of Science and Technology in Education, Journal of Education and Counseling, 3(1): 101-109

Nurdin Usman. (2002). Definition of Implementation in his book with the title Context of Curriculum-Based Implementation. https://pendidikan.co.id/implementasi-adalah/ January 5, 2022

Omeri, Nopan. (2015). The Importance of Character Education in the World of Education, Journal of Educational Managers. 9(3): 464-468.

Sanusi. (2017). Integration of Al-Quran, Science and Social Sciences as a Model Base for the Development of Social Studies Teaching Materials in Madrasas. Journal IJTIMAIYA. 1(1): $129-146$

Utomo.S.T. (2019). Implementation of Technology and Science in Islamic-Based Islamic Boarding Schools in the Archipelago. Research journal. 13(2): 305-324

Law of the Republic of Indonesia (2013) No. 20 of 2003 Article Concerning the National Education System. Jakarta: CV Multi Persindo

Widyawati, Setya (2013). philosophy of science as the basis for the development of science education. Gelar J. Seni Budaya 11(1): 87-96. 